\title{
Measuring and analysing standardisation in the Hungarian hotel sector
}

\author{
Medindo e analisando a padronização no setor hoteleiro húngaro
}

Petra Gyurácz-Németh

University of Pannonia, Veszprém, Egyetem u. 10, 8200, Hungary, nemeth@turizmus.uni-pannon.hu

\begin{abstract}
In tourism and the hotel sector standardisation is sometimes an advantage and other times a disadvantage, though it has been mentioned several times. This research explores the topic of standardisation in the Hungarian hotels. The paper determines the level of standardisation in hotels and the extant of the relationship between the level of standardisation and the hotel affiliation, the Hotelstars Union membership, the number of rooms and the star rating. There are 81 questionnaires filled out by hotel general managers of those hotels which belong to the Hungarian Hotel and Restaurant Association. Only the three-, four- and five-star hotels were questioned by this survey.
\end{abstract}

The results show that the level of hotel standardisation depends on the hotel chain membership but only weakly by $5 \%$. There are also proven significant relationships with the Hotelstars Union membership, the number of rooms and the star rating of the hotels.

Keywords: Standardization, hotel, chains, hotel stars, rooms.

\section{Resumo}

No turismo e no setor hoteleiro a padronização é, por vezes, uma vantagem e outras vezes uma desvantagem, embora tenha sido mencionada várias vezes. Esta pesquisa explora o tema da padronização nos hotéis húngaros. O documento determina o nível de padronização em hotéis e o relacionamento existente entre o nível de padronização, a afiliação hoteleira, a associação do Hotelstars Union, o número de quartos e a classificação em estrelas. Conseguimos 81 questionários preenchidos pelos gerentes gerais dos hotéis que pertencem à Associação Húngara de Hotéis e Restaurantes. Somente os hotéis de três, quatro e cinco estrelas foram questionados para esta pesquisa.

Os resultados mostram que o nível de padronização do hotel depende da adesão à cadeia hoteleira, mas apenas ligeiramente em $5 \%$. Também há relações importantes comprovadas com a adesão da Hotelstars Union, o número de quartos e a classificação em estrelas dos hotéis.

Palavras-chave Padronização, hotel, cadeias, estrelas do hotel, salas.

\section{Introduction}

The topic of standardization has always been a debate in the production and service literature as well as among tourism experts. Every researcher has a point of view about standardization not always using the same term but the same meaning. In hotels standardization became the part of everyday operation for chain members.

This research is unprecedented, there could not be any existing questionnaires, which had been applied in the process, because there was not any, where the research could start from.

It has always been obvious that standardization exists in the hotel industry and that standards are used in the everyday operation, but the level of standardization has not been measured before. The level of standardization has never been applied to compare hotels to each other and there has been no information about the standardization of independent hotels either, it has always been a privilege of hotel chains. The role of the hotel characteristics in the level of standardization has not been identified either, but they could help to get to know the commonly used term of standardization and collect information about the hotel practices in different countries, in this case Hungary. This paper wants to reveal the exact level of standardization in different hotels in Hungary and find out more information about this commonly used and known phenomenon. The objective of this research was to get to know more about standardization in the hotel sector and find out if there is a relationship between the level of standardization and the following important hotel characteristics: chain membership, Hotelstars Union membership, room number and star rating. These are the most basic and commonly used characteristics of hotels, which could specify the hotel among accommodation experts.

The analysis of the hypotheses concerning the relationship between the hotel characteristics and the level of standardisation was carried out by an IBM SPSS software package and Microsoft Excel, where different analytical techniques were applied: FisherCochran theorem, analysis of variance, Pearson correlation and one-way ANOVA with post hoc analyses.

The paper first explains the definition and meaning of standardization as well as the advantages of applying it in different sectors, and then the Hungarian hotel sector is introduced. It is followed by the presentation of the hypotheses. The introduction of the used methodology and calculations are in the next section concentrating on the determination of the standardization level of the hotel, and then the results are presented with the help of the SPSS output tables. At the end of the paper, the conclusions are stated as well.

\section{Literature review}

The literature review includes some of the most important theories, definitions considering standardisation and introduces the Hungarian hotel sector and its characteristics, supporting the exact research presented in the following chapters.

\subsection{Standardisation}

Standardisation is not the only term which can be used for the same meaning. The different authors called standardisation differently when they wanted to explain a similar phenomenon. Table 1 comprises the most common terms used for standardisation. 
Table 1 - The different phrasing of standardisation

\begin{tabular}{|c|c|c|c|}
\hline Author, date & Standardisation & Author, date & Standardisation \\
\hline $\begin{array}{l}\text { Sasser, Olson \& Wyckoff, } \\
1978\end{array}$ & Mass production & Kurtz \& Clow, 1998 & Cost efficiency \\
\hline Surprenant \& Solomon, 1987 & Predictability & Mesdag, 2000 & $\begin{array}{l}\text { Globalisation, } \\
\text { standardisation }\end{array}$ \\
\hline Juran, 1988 & Meeting customer needs & Ritzer, 2001 & McDonaldization \\
\hline Kimes \& Mutkoski, 1991 & Procedural dimension & Tether, Hipp \& Miles., 2001 & Economy of scale \\
\hline Lovelock, 1992 & Operation & Sundbo, 2002 & Economics of predictability \\
\hline Baalbaki \& Malhotra, 1993 & Globalisation & $\begin{array}{l}\text { van Looy, Gemmel \& van } \\
\text { Dierdonck., } 2003\end{array}$ & Execution \\
\hline Upton, 1994 & Uniformity & Cloninger \& Swaidan, 2007 & Homogeneous \\
\hline $\begin{array}{l}\text { McCutcheon, Meredith \& } \\
\text { Raturi., } 1994\end{array}$ & Responsiveness & Veres, 2009 & $\begin{array}{l}\text { Undifferentiated market } \\
\text { influence }\end{array}$ \\
\hline $\begin{array}{l}\text { Lovelock, Vandermerwe \& } \\
\text { Lewis, } 1996\end{array}$ & Cycle of Mediocrity & Kotler \& Armstrong, 2010 & Productivity \\
\hline Lampel \& Mintzberg, 1996 & Aggregation & Heppel, 2010 & Systemise! \\
\hline $\begin{array}{l}\text { Anderson, Fornell \& Rust, } \\
1997\end{array}$ & Productivity & $\begin{array}{l}\text { Nordin, } \quad \text { Kindström, } \\
\text { Kowalkowski \& Rehme, } 2011\end{array}$ & $\begin{array}{l}\text { Transferability } \\
\text { markets }\end{array}$ \\
\hline $\begin{array}{l}\text { Silvestro, } \quad \text { Fitzgerald, } \\
\text { Johnston \& Voss, } 1997\end{array}$ & Mass service & $\begin{array}{l}\text { Johnston, Clarke \& Shulver, } \\
2012\end{array}$ & Inside-out \\
\hline Irons, 1997 & Threshold values & Johnston et al., 2012 & Commodity \\
\hline
\end{tabular}

Standardisation is the situation where the service product is the same every time (like a McDonald's hamburger) (Sundbo, 2002). It is the right means to decrease costs, as well as increasing productivity and lowering prices (Sundbo, 2002). According to Sundbo (1994) standardisation can be explained with the term: economy of productivity. This logic means that only prices and quantities exist and consumers are supposed to assess the quality of a product and compare the price to similar products (Sundbo, 1994). This logic emphasises the price and believes that the price rules the market and it determines the customers' decision. This theory is supported by Tether et al's (2001) research as well, which states that the role of standardised services arises in price sensitive markets, where the production is routine and the labour cost is low and with relatively low education (Tether et al., 2001). Researchers also suggest that the standardised product is also homogeneous, which means it is standardized with very little adaptation or heterogeneity (Cloninger \& Swaidan 2007).

McDonaldization is also used for standardisation since McDonalds was the first company in the food industry to apply this concept professionally. The term was elaborated by Ritzer (2001) and means low price (due to low costs), low quality, fast service delivery and predictability all over the world. This theory is very important from the hotels' point of view since global hotels have to make sure that their services are the same everywhere and it can provide predictability for the guests. Ritzer's idea can also be criticised for not containing customer experience and employee satisfaction in the model (Weaver, 2005).

The other aspect of standardisation is to support the globalisation aspiration of the company and the term is commonly used in international perspective. This association is essential for hotel chains to go global and find the solution for

that, but they still need to develop products or services that will suit the foreign market (Mesdag, 2000). Although it is also suggested that for example the standardised advertising only works in those counties, where there are a lot of similarities (Samiee, Jeong, Pae \& Tai., 2003).

It is important to state that not only multinational corporations can gain advantage from the nature and practice of standardisation. In restaurants the most important aim is efficiency and efficient service delivery which is true for independent restaurants as well. In leisure firms assuring service quality becomes a critical factor and according to Gilpin and Kalafatis (1995) the UK leisure firms are able to use standardisation for cost effectiveness as well as providing consistent quality.

Zeithaml and Bitner (1996) agree with them and add that those companies that are successful in their performance and known for high quality level are likely to establish operations standards to help their employees and guide them through their service providing activities (Zeithaml, Bitner \& Gremler, 2009). Table 2 shows the most important advantages mentioned by researchers.

Table 2 - Some advantages of standardisation

\begin{tabular}{|c|c|}
\hline Author & Advantage of standardisation \\
\hline $\begin{array}{l}\text { Kimes \& } \\
\text { Mutkoski, } 1991\end{array}$ & Efficiency, efficient service delivery \\
\hline Sundbo, 1994 & Increased productivity \\
\hline Ritzer, 2004 & $\begin{array}{l}\text { Efficiency, calculability, predictability, } \\
\text { control through nonhuman } \\
\text { technology }\end{array}$ \\
\hline Heppel, 2010 & Fast, predictable, perfect service \\
\hline
\end{tabular}


Although there are several advantages for applying standardisation, there are other factors, which have to be considered. Mostly standardisation requires a more rigid hierarchy (Sasser et al., 1978), so too much standardisation can make the hotel unable to adapt to the circumstances flexibly. Not every researcher shares this point since Kakavelakis (2010) found that standardisation and tight, bureaucratic control system do not relate with each other and standardisation can even help emphasise family in the company as well, which is an important theory for small hotels in Hungary. It is also a good solution if the routine processes are standardised and the others are intact (Heppel, 2010). It could also work if the company does not apply strict and mechanistic standards but a framework, which is based on customers' needs and values (Irons, 1997).

Standards are not same they have different style, different content, so they can be grouped into distinct categories. According to Nesheim (1990) four types of standards can be defined. Nesheim (1990) mainly concentrated on the organisational design and wanted to find the best coordination mechanism for different service firms. The four groups are (Table 3):

\section{Table 3 - Type of standards based on Nesheim (1990)}

\begin{tabular}{|l|l|l|}
\hline \multicolumn{1}{|c|}{ Type of standards } & \multicolumn{1}{c|}{ Hotel example } \\
\hline $\begin{array}{l}\text { Standardisation of } \\
\text { processes or output }\end{array}$ & $\begin{array}{l}\text { Room cleaning process and the } \\
\text { number of rooms which needs to } \\
\text { be done until the end of the day } \\
\text { per room attendant }\end{array}$ \\
\hline $\begin{array}{l}\text { Standardisation of work } \\
\text { processes }\end{array}$ & \begin{tabular}{l} 
Hotel reservation process \\
\hline Standardisation of output
\end{tabular} & $\begin{array}{l}\text { The arrangement of the rooms } \\
\text { when the guests arrive }\end{array}$ \\
\hline Cultural control & $\begin{array}{l}\text { The process of welcoming guests } \\
\text { on arrival }\end{array}$ \\
\hline \multicolumn{2}{|c|}{ Source: Own compilation. } \\
\hline
\end{tabular}

The typology contains hotel examples as well. Although the standard classification has not been made to group hotel standards but as it can be seen hotel standards can be classified into the originally management purpose categories.

As the literature review shows, although standardisation has not been found out for accommodation service providers but it can definitely be interpreted from a hotel perspective as well.

\subsection{Hungarian hotel sector}

Tourism is one of the most important industries in the Hungarian economy, its contribution to the Hungarian GDP was 9\% in 2014. The accommodation sector's revenue reached approximately 691 million euros $(214.283 .806 .000 \mathrm{Ft})$ in 2015. From this great number $89 \%$ was produced by the hotel sector, which means that this is the most significant type of the accommodation facilities, although their number is much lower (32\%) than other accommodation types. The sector is increasing in the last five years, the most important hotel performance numbers (average room rate, occupancy rate, revenue per available room, gross revenue) are rising every year.
Hotels are distinguished by ratings mostly determined by the government of the country they are situated (Pizam \& Holcomb, 2008). The star as a symbol is most commonly applied by these systems, although it is essential to mention that these rating standards are not globally harmonised (Hassanien, Dale \& Clarke, 2010). In Hungary the stars are provided and controlled by the Hotelstars Union system in cooperation with the Hungarian Hotel \& Restaurant Association. Hotelstars Union have 16 member countries where their standards are applied for the hotels. Hungary was one of the first countries to enter into this international system. In these countries the classification of hotels is harmonised and they use the common standards and procedures. The guests know what the different stars mean and there is a board at the hotels' entrance showing that they were accredited by Hotelstars Union. It should also be added that the accreditation process is not compulsory, but only those hotels can use the stars as symbols, which got the certification from the Hotelstars Union.

\subsection{The hypotheses}

For defining the hypotheses those characteristics were applied which are the most basic and commonly used features in the hotel industry.

Hypothesis 1: There is a relationship between chain membership and the level of standardisation.

Chain membership has an essential role related to the topic, hotel standardisation, because hotel chains have been dealing with standardisation for several decades.

Hypothesis 2: There is a relationship between Hotelstars Union membership and the level of standardisation.

Hotelstars Union as it is detailed earlier is the official star rating system in Hungary and its mission is to assure quality through 270 criteria, which can be called standards although mostly not service delivery standards, so it was an interesting question to see if the hotels accredited by the Hotelstars Union are more standardised or not. Hotelstars Union is mentioned in academic articles for example Radojevic, Stanisic \& Stanic (2015).

Hypothesis 3: There is a relationship between the number of rooms in the hotel and the level of standardisation.

Hypothesis 4: There is a relationship between the star rating of the hotel and the level of standardisation.

Star rating is one of the most important and mentioned characteristic of hotels from the guests' and experts' point of view as well. It often appears in academic researches like Rhee \& Yang (2015), where star rating is an essential factor in a hotel. The exact question is if the higher qualified hotels are more standardised than the lower ones.

\section{Methodology}

The aim of the research was to measure standardization and be able to find the relationship between standardization and some of the characteristics of hotels. There are plenty of theories and 
practice of standardization in the hotel sector, though the measurement of it was not so obvious, that is the reason why a unique method had to be developed. The method was created by using a hotel chain's so-called standard book, which contains the most important hotel process guidelines. Since these books include hundreds of standards, the number of variables had to be reduces. The exact operation standards are classified into groups according to the process they refer to (for example check-in, check-out standards). The author chose only these groups (standard groups) to be asked in the questionnaire, so 44 categories were defined. The respondents had to decide if the processes in the standard groups actually exist in the hotel, because if they did not, then these processes were excluded from further analyses. If the service existed in the hotel but it was not standardized at all, they got one point to be calculated with but should not get more points in the determination of the final level of standardization. If the process existed in the accommodation provider and it was orally standardized only, which means that there is a custom how the service is delivered in the hotel but there is no handbook or exact written guidelines about it, then the hotel got two points for that service group. The best case scenario (the strictest standardization) is when the service delivery process exists in the hotel and it is standardized in writing as well, which means that the company has a so-called standard book, which can be handed to the new recruited staff and the standards there are to be followed.

However, according to practice the standard groups do not have the same importance, so hotel experts had to be asked to share their opinion and determine a weight for each groups. Six structured interviews have been made with hotel managers. The selection criteria to choose the right respondents was to have experience in management position in a hotel chain member hotel, because this made sure, that they had to work with standards and know their importance. They had to evaluate the above mentioned 44 standard groups in a 1-7 Likert scale to define the differences in their weights. They were also requested to determine the weight of written and oral standards as well. With this measurement method it is possible to define the standardization level of the hotels in the Hungarian hotel sector.

The sample criteria were that the hotel had to be a member of the Hungarian Hotel \& Restaurant Association, because the star category system in Hungary was not determined at the beginning of the research design, so this association gave a firm basis about the hotels' attitude to quality. Only three-, four-and five-star hotels could be in the sample, since their role in the Hungarian economy and inside the hotel sector is significantly higher (according to the data of the Hungarian statistics office) comparing to the one- and two-star hotels which number is very low (three one-star hotel and 13 two-star hotels) in the association as well. The respondents could only be hotel general managers, because the research topic is very complex and contains information about all the departments and processes in the hotel.
At the same time other information had to be gathered since the basic data of hotels had to be found out to prove the hypothesis that these characteristics have a relationship with the level of standardization. So the first part of the questionnaire contained the hotel chain affiliation, Hotelstars Union membership, number of rooms in the hotel and star rating.

The data collection was carried out via online and asked personally (20\%). Personally asking questionnaires could give more context and provide more information and some opinions of the hotel general managers as well. The link of the questionnaire was sent to 366 hotel general managers and 81 full answers were analysed.

After all the information has been gathered the data were put into a table, where the standard groups, the weights and the answers were next to each other. Different numbers have been assigned to different answer options. If the hotel does not have that service (standard groups) they get no indicator, if they have the service but it is not standardized they get a 1 , if they have the service but only orally standardized, they get 2 , if they have the service and the standardization process is written down, they get a 3. After that all the numbers are ready to be calculated with. The first step is to multiply the given number with the weights of the standard groups, and then the written or oral standard weights then sum it up. Since a percentage is a very understandable and well-applicable number in practice, a standardization percentage has been produced. The standardization level percentages can be well interpreted and compared to each other. Then the data besides the hotel characteristics were copied into SPSS software and analysed. Different statistical methods have been used: Fisher-Cochran theorem, analysis of variance, Pearson correlation analysis, analysis of variance with post-hoc analysis.

\section{Results and discussion}

The four hypotheses are being answered in this section. The findings are grouped by the different hypothesis and the results are presented by SPSS outputs as well.

\subsection{The relationship between the level of standardisation and hotel chain affiliation}

The first hypothesis was to find out how much hotel chain membership influences the level of standardisation. The assumption is that it has to have a lot of effect on the level of standardisation, since hotel chains have their own regulations for every service delivery process, which is compulsory to keep for every hotel chain member hotels. The proper application of these standards are checked every year by mystery shoppers. To analyse the relationship between the two variables, FisherCochren theorem has been apply to determine not only the connection but the strength of the influence as well. Table 4 shows the result of the analysis of the relationship between the hotel chain membership and the level of standardisation. 
Table 4 - The result of testing the relationship between hotel chain membership and the level of standardisation

\begin{tabular}{|l|c|c|c|}
\hline & Chain member & Not a chain member & Altogether \\
\hline Number of hotels & 19 & 62 & 81 \\
\hline Variance ratio between groups & 5.0362447 & & \\
\hline Variance ratio within groups & 94.963755 & & \\
\hline Variance ratio (H) & 0.2244158 & & \\
\hline
\end{tabular}

Source: Own compilation.

As it can be seen in Table 4, there were 19 hotel chain members and 62 independent hotels in the sample. The results show that there is however a significant relationship between the two factors but the strength of this connection, as Variance ratio $(\mathrm{H})$ shows, is weak (0.2244158) Since the exact size of the influence was one of the most important factors to define, which is only $5 \%$, so it can be stated, that hotel chain affiliation has a relationship with the level of standardisation though the number is low. This outcome means that $95 \%$ of the level of standardisation is influenced by other factors, so hotel chain affiliation is not the only one which determines if a hotel uses standardisation or not or that the level of hotel standardisation is only dependent on the chain membership. An independent hotel can also be standardized; sometimes more than a chain member, it does not have to belong to a hotel chain to be able to apply standardisation in its everyday operation. As the research shows, in the Hungarian hotel sector the independent hotels can be as standardized as chain members. Although it should also be mentioned that independent hotels have to create their own standards which requires high resources, but hotel chain member hotels are given the operation standards by the hotel chain, so for them it is easier and faster to apply standardisation. Those independent hotels have an advantage which general manager or department leaders have experience working in hotel chains and can use the standards they learnt there.

\subsection{The relationship between the level of standardisation and} Hotelstars Union membership

The second hypothesis wanted to discover the relationship between the Hotelstars Union membership and the level of standardisation. As it has already been mentioned not all the Hungarian hotels are classified by the Hotelstars Union, which organisation is supposed to be responsible for the hotel accreditations. The reason for assuming that there is a relationship between these two factors is that Hotelstars Union has its regulations for all the hotels which want the star classification, so they surely have to keep those standards anyway and get used to apply written standards in their operation. The hypothesis was tested by one-way analysis of variance. Table 5 shows that there is a significant difference between Hotelstars Union member hotels and those which are not members of the association from the perspective of the level of standardisation. It means that Hotelstars Union membership has an impact on the level of standardisation. Although it should also be mentioned that the direction of the relationship cannot be determined by the above mentioned analyses method, so it can also be stated that those hotels which had already introduced standards can be much more successful in the Hotelstars Union accreditation process, because they are used to standards, they can have stricter standards than what Hotelstars Union requires.

Table 5 - The result of testing the relationship between Hotelstars Union membership and the level of standardisation

\begin{tabular}{|l|c|c|c|c|c|}
\hline & \multicolumn{3}{|c|}{ ANOVA } & & S \\
\hline & Sum of Squares & df & Mean Square & F \\
\hline Between Groups & 493480.622 & 1 & 493480.622 & 7.963 & .006 \\
\hline Within Groups & 4896016.510 & 79 & 61974.893 & & \\
\hline Total & 5389497.132 & 80 & & \\
\hline
\end{tabular}

Source: Own compilation.

4.3 The relationship between the level of standardisation and the number of rooms

The third hypothesis was stated to prove if bigger hotels are more standardized than smaller ones. The reason for the assumption was that the general managers loses their direct control in larger hotels because of their complexity and number of services, so it is more necessary to apply standardisation to assure quality and provide guests the service they expect. In Hungary it is also true that bigger hotels tend to affiliate to hotel chains, because of the initial costs and bank loan. The result of the Pearson correlation analysis can be seen on Table 6 .

Table 6 - The result of testing the relationship between the size of the hotel and the level of standardisation

\begin{tabular}{|l|c|c|c|}
\hline \multicolumn{2}{|c|}{ Correlations } & & Number of rooms \\
\hline Level of standardisation & & Level of standardisation & $.330^{* *}$ \\
\hline & Pearson Correlation & 1 & .003 \\
\hline Number of rooms & Sig. (2-tailed) & & 81 \\
\hline & N & 81 & 1 \\
\hline
\end{tabular}

**. Correlation is significant at the 0.01 level (2-tailed). Source: Own compilation. 
There is a significant relationship between the level of the hotel standardisation and the number of rooms in the Hungarian hotel sector. The nature of the relationship can be seen in Table 6 as well, it is a positive relationship, which means that the larger the hotel is, the higher standardisation level can be found there. The intensity of the relationship is weak, since the coefficient is 0.33 , so it can be stated that the relationship is significant, although not so strong.

The professional logic and the third hypothesis has been proven, which means that the bigger hotels apply standardisation more than smaller ones. In Hungary smaller hotels mostly belong to families and the ownership of the hotel is the same as the management, so professional management teams are not always employed. It means that there is less opportunity for these hotels to learn from the hotel chains because the owners may not have any past experience to use for standardisation.

\subsection{The relationship between the level of standardisation and the star rating of the hotel}

The star rating of the hotels is one of the most important indicators of the hotel from the guest and professional point of view as well. According to the fourth hypothesis there should be a relationship between the star rating of the hotel and the level of standardisation. In the author's opinion there should be a difference among three-, four- and five-star hotels (the analysed types) categories' standardisation level. Since different stars mean different quality level and number of service, it would be logical to assume that the difference in the level of standardisation should be also seen. One-way analyses of variance were applied to test the hypothesis. Table 7 presents the results of the fourth hypothesis, which shows that there is a significant relationship between the star category of the hotel and their level of standardisation, so there is a difference among the level of standardisation of hotels concerning their star rating. Although the outcome of the analysis is clear, more evaluation was needed to find out where the difference is.

Table 7 - The result of testing the relationship between the star rating of the hotel and the level of standardisation

\begin{tabular}{|l|c|c|c|c|c|}
\hline & \multicolumn{3}{|c|}{ ANOVA } & F & Sig. \\
\hline Between Groups & Sum of Squares & df & Mean Square & . \\
\hline Within Groups & 451708.500 & 2 & 225854.250 & 3.568 & .033 \\
\hline Total & 4937788.632 & 78 & 63304.982 & & \\
\hline
\end{tabular}

Source: Own compilation.

Table 8 shows the results of the Post hoc test following the analysis of variance. Table 8 shows that the difference is between three- and five-star hotels. It means that there is no significant difference in the standardisation level between fourand five-star or three- and four-star hotels but the difference is significant between five- and three-star hotels. The reason of that can be found that the quality, the number and level of services is very different in a Hungarian three-star and five-star hotel than between the categories close to each other, so the explanation can be the distance between the categories.

Table 8 - The result of the Post hoc test

\begin{tabular}{|c|c|c|c|c|c|c|c|c|}
\hline \multicolumn{9}{|c|}{ Multiple Comparisons } \\
\hline \multicolumn{9}{|l|}{ LSD } \\
\hline \multirow{2}{*}{\multicolumn{2}{|c|}{ (I) Star rating }} & \multirow{2}{*}{\multicolumn{2}{|c|}{ (J) Star rating }} & \multirow{2}{*}{ Mean Difference (I-J) } & \multirow{2}{*}{ Std. Error } & \multirow{2}{*}{ Sig. } & \multicolumn{2}{|c|}{ 95\% Confidence Interval } \\
\hline & & & & & & & Lower Bound & Upper Bound \\
\hline \multirow{6}{*}{ dimension2 } & \multirow{2}{*}{3} & \multirow{2}{*}{ dimension3 } & 4 & -107.034 & 61.840 & .087 & -230.15 & 16.08 \\
\hline & & & 5 & $-273.305^{*}$ & 107.591 & .013 & -487.50 & -59.11 \\
\hline & \multirow{2}{*}{4} & \multirow{2}{*}{ dimension3 } & 3 & 107.034 & 61.840 & .087 & -16.08 & 230.15 \\
\hline & & & 5 & -166.271 & 101.664 & .106 & -368.67 & 36.13 \\
\hline & \multirow{2}{*}{5} & \multirow{2}{*}{ dimension3 } & 3 & $273.305^{*}$ & 107.591 & .013 & 59.11 & 487.50 \\
\hline & & & 4 & 166.271 & 101.664 & .106 & -36.13 & 368.67 \\
\hline
\end{tabular}

*. The mean difference is significant at the 0.05 level.

Source: Own compilation.

\section{Conclusion}

The objective of the research was to measure the level of standardisation of Hungarian hotels and find out if some of the most important characteristics influence this level or not.

The first hypothesis was to find out the nature of the relationship between the hotel chain affiliation and the standardisation level of the hotel. The result suggests that the hotel chain membership helps to raise the level of standardisation but only by $5 \%$. From a professional point of view, it means that an independent hotel can be as standardised as a hotel chain member. The reason for that can be the hotel chain experience of the general manager who could introduce similar standards in the new hotel as well.

The second topic was the influence of the Hotelstars membership on the level of standardisation. This issue matters because it is not compulsory to be accredited by the Hotelstars Union, so it was important to prove that the evaluation can be useful for the hotels from the standardisation point of view as well. The result suggests that the hypothesis was right, because 
the relationship between the two variables has been proven, although the logic starting from another direction which says that for those hotels which already have standards it is easier to adapt to the new ones which are determined by the Hotelstars Union.

The relationship between the size of the hotel (presented by the number of rooms) and the level of standardisation has also been confirmed. This time the type of the relationship could be determined as well and it could be stated that the bigger the hotel is, the higher level of standardisation it has. It does not mean the smaller hotels cannot use standardisation, only that it is more commonly applied by bigger hotels. Although the relationship is weak, so the connection between the two variables is not without exceptions.

The last hypothesis had to be more extendedly examined. It was about the well-known star rating of the hotel and the level of standardisation. The difference could be found between fiveand three-star hotels, which is not surprising because the researcher knows the Hungarian hotel sector. Three-star hotels are not as developed, mostly independent and smaller hotels than the four- and five-star hotels mostly general managers, who has not gained any experience abroad or at chain hotels.

The most important limitation of the research is the low number of respondents which comes from the fact, that the questionnaire was made for larger research and it had 22 pages, which had to be filled by only general managers. General managers are those employees in the hotel who are very difficult to reach and persuade to take time and participate in an extensive research. Besides the standards are most of the time confidential in hotels and the questionnaire contained information about the revenue and other performance indicators of the hotel. Unfortunately, the sample is not representative either concerning the location, the type or size of the hotels.

In the future two other stakeholders are planned to ask about hotel standardisation. guests and employees. The hotel staff would be essential to involve in the survey because of their experience or lack of experience with hotel standards. This way the real advantages and disadvantages of standards could be determined by practice. This process could be investigated by observation. Since guests are the ones to decide if they got quality service or not, they should be questioned as well about the experience with standards and the most important processes for them in hotels. Besides involving other stakeholders in further research, an international approach should be applied as well. It would be very interesting to investigate another country's hotel sector and compare the results to the Hungarian findings concerning the level of standardisation and hotel characteristics.

\section{References}

Anderson E. W., Fornell, C. \& Rust R.T. (1997). Customer Satisfaction, Productivity and Profitability: Differences Between Goods and Services. Marketing Science, 16(2), 129-145.
Baalbaki I. B. \& Malhotra N. K. (1993). Marketing management bases for international market segmentation: an alternate look at the standardization/customization debate. International Marketing Review, 10(1), 19-44.

Cloninger P. A. \& Swaidan Z. (2007). Standardization, customization and revenue from foreign markets. Journal of Global Marketing, 20 (2/3), 57-69.

Gilpin, S.C. \& Kalafatis, S.P. (1995). Issues of product standardisation in the leisure industry. The Service Industries Journal, 15(2),186-202.

Hassanien, A., Dale, C. \& Clarke, A. (2010). Hospitality business development. Oxford: Butterworth-Heinemann.

Heppel, M. (2010). 5 Star Service: how to deliver exceptional customer service. Harlow: Pearson.

Irons, K. (1997). The marketing of services: a total approach to achieving competitive advantage. Cambridge: McGraw-Hill.

Johnston, R., Clark, G. \& Shulver, M. (2012). Service operations management: improving service delivery. Harlow: Pearson.

Juran, J. M. (1988). Juran's quality control handbook. New York: McGraw Hill.

Kakavelakis, K. (2010). Family-themed control in "service factories": an examination of modes of service delivery and HRM styles in the UK restaurant sector. Personnal Review, 39(5), 557-573.

Kimes, S.E. \& Mutkoski, S.A. (1991). Assessing customer contact: work sampling in restaurants. The Cornell Hotel and Restaurant Administration Quarterly, 32 (1), 82-88.

Kotler, P. \& Armstrong, G. (2010). Principles of marketing. London: Pearson.

Kurtz, D.L. \& Clow, K.E. (1998). Services marketing. New York: John Wiley \& Sons Inc.

Lampel, J. \& Mintzberg, H. (1996). Customizing customization. Sloan Management Review, 38, 21-30.

Lovelock, C. (1992). Seeking synergy in service operations: seven things marketers need to know about service operations. European Management Journal, 10(1), 22-29.

Lovelock, C., Vandermerwe S. \& Lewis B. (1996). Services marketing: an European perspective. Berwick-upon-Tweed: Prentice Hall.

McCutcheon, D.M., Meredith J.R. \& Raturi, A.S. (1994). The customization-responsiveness squeeze. Sloan Management Review, Winter, 89-104.

Mesdag, van, M. (2000). Culture-sensitive adaptation or global standardization: the duration-of-usage hypothesis. International Marketing Review, 17(1), 74-84.

Nesheim, T. (1990). Service management and organizational design. Scandinavian Journal of Management, 6(3), 181-195.

Nordin, F., Kindström, D., Kowalkowski, C. \& Rehme, J. (2011). The risk of providing services, differential risk effects of the servicedevelopment strategies of customisation, bundling, and range. Journal of Service Management, 22(3), 390-408.

Pizam, A. \& Holcomb, J. (2008). International Dictionary of Hospitality Management. Oxford: Elsevier.

Radojevic, T., Stanisic, N. \& Stanic, N. (2015). Ensuring positive feedback: factors that influence customer satisfaction in the contemporary hospitality industry. Tourism Management, 51, 13-21.

Rhee, H.T. \& Yang, S-B. (2015). Does hotel attribute importance differ by hotel? Focusing on hotel star-classifications and customers' overall ratings. Computers in Human Behavior, 50, 576-587.

Ritzer G. (2001). Exploration in the sociology of consumption, fast food, credit cards and casinos. London: Sage.

Ritzer, G. (2004). The McDonaldization of society, revised new century edition. Thousand Oaks: Sage.

Samiee, S., Jeong, I., Pae, J.H \& Tai, S. (2003). Advertising standardization in multinational corporations: the subsidiary perspective. Journal of Business Research, 56(8), 613-626. 
Sasser, W. E., Olson, R. P. \& Wyckoff, D. D. (1978). Management of service operations: text, cases and reading. Boston: Allyn \& Bacon.

Silvestro R., Fitzgerald, L., Johnston R. \& Voss, C. (1997). Towards a classification of service processes. In M. Gabott, G. Hogg (eds.), Services Marketing Management (pp. 361-374). Orlando: The Dryden Press.

Sundbo, J. (1994). Medullisation of service production and a thesis of convergence between service and manufacturing organizations. Scandinavian Journal of Management, 10(3), 245-266.

Sundbo, Jon (2002). The service economy: standardisation or customisation? The Service Industries Journal, 22(4), 93-116.

Surprenant, C.F. \& Solomon, M.R. (1987). Predictability and personalization in the service encounter. Journal of Marketing, 51(April), 73-80.

Tether B.S., Hipp C. \& Miles I (2001). Standardisation and particularisation in services: evidence from Germany. Research Policy, 30(7), 1115-1138.

Upton, D.M. (1994). The management of manufacturing flexibility. California Management Review, 36(2), 72-89.

Van Looy, B., Gemmel, P. \& van Dierdonck, R. (2003). Services management: an integrated approach. Glasgow: Prentice Hall.

Veres, Z. (2009). A szolgáltatásmarketing alapkönyve. Budapest: Akadémiai Kiadó.

Weaver, A. (2005). The McDonaldization thesis and cruise tourism. Annals of Tourism Research, 32(2), 346-366.

Zeithaml, V.A. \& Bitner, M.J. (1996). Services marketing. Singapore: McGraw-Hill.

Zeithaml, V.A., Bitner, M.J. \& Gremler, D.D. (2009). Services marketing: integrating customer focus across the firm. Singapore: McGraw-Hill.

Received: 19 January 2017

Revisions required: 13 April 2017

Accepted: 20 September 2017 